UDK 305-055.2(497.5 Zagreb)“12/14“

$347.65 / .68\left(497.5\right.$ Zagreb)" $12 / 14^{“}$

94(497.5 Zagreb)"12/14“

Primljeno: 1. 10. 2017.

Prihvaćeno: 9. 10. 2017.

Izvorni znanstveni rad

DOI: $10.22586 /$ pp.v53i2.50

\title{
Prikrivena moć. Uloga pripadnica gradske elite u političkom, društvenom i gospodarskom životu zagrebačkoga Gradeca
}

\author{
Marija Karbić \\ Hrvatski institut za povijest \\ Podružnica za povijest Slavonije, Baranje i Srijema \\ Ante Starčevića 8 \\ 35000 Slavonski Brod \\ Republika Hrvatska \\ E-adresa: mkarbic@isp.hr \\ Bruno Škreblin \\ Hrvatski institut za povijest \\ Opatička 10 \\ 10000 Zagreb \\ Republika Hrvatska \\ E-adresa: bruno@isp.hr
}

U radu se nastoji pokazati kakva je bila uloga pripadnica gradske elite u zagrebačkome Gradecu. Upozorava se da su, iako direktno nisu sudjelovale u gradskoj vlasti, bile usko povezane s njezinim nositeljima. Govori se o njihovoj ulozi u prijenosu vlasništva i društvenoga ugleda kao i stvaranju političkih veza te time i formiranju gradske elite.

Ključne riječi: povijest žena, gradske elite, srednjovjekovna Slavonija, nasljedno pravo

Povijest žena u srednjem vijeku pozornost istraživača privlači već nekoliko desetljeća, što je rezultiralo nizom studija posvećenih ženama iz različitih društvenih slojeva diljem srednjovjekovne Europe. ${ }^{1}$ Te studije su pokazale postojanje znatnih

Ovaj je rad sufinancirala Hrvatska zaklada za znanost projektom "Gradovi hrvatskog srednjovjekovlja: Urbane elite i urbani prostor", broj IP-2014-09-7235.

1 O počecima istraživanja povijesti žena vidi u: Katalin G. Szende, "The Other Half of the Town: Women in Private, Professional and Public Life in Two Towns of Late Medieval Western Hungary", u: Wo- 
razlika u njihovu položaju s obzirom na područje o kojem je riječ, na to radi li se o plemkinjama ili ne, žive li u gradovima ili na selu, kojem sloju pripadaju. ${ }^{2} \mathrm{U}$ ovom radu nastojat ćemo osvijetliti položaj i ulogu još jedne skupine žena - pripadnica gradske elite zagrebačkoga Gradeca.

Pripadnice gradske elite u zagrebačkome Gradecu nisu direktno mogle sudjelovati u obnašanju vlasti u gradu, to jest vršiti neku od funkcija u gradskoj upravi niti su imale pravo birati članove gradskoga magistrata, ali usprkos tome njihov utjecaj na život u gradu ne treba podcijeniti. Kako bismo pokazali kako su utjecale na različite sfere života, osvrnut ćemo se na njihovu gospodarsku snagu, ulogu u prijenosu vlasništva nad nekretninama, kao i društvenog statusa, stvaranju političkih veza i formiranju gradske elite. ${ }^{3} \mathrm{O}$ navedenim pitanjima nastojali smo progovoriti na temelju primjera nekih pripadnica ovoga sloja, ograničivši se pritom na razdoblje od druge polovine 14. stoljeća do sredine 15. stoljeća. S obzirom na ova ograničenja oprez pri stvaranju zaključaka je nužan, ali držimo da su određene spoznaje moguće, iako dodatnu poteškoću predstavljaju i vrela kojima raspolažemo, a koja o mnogim stvarima šute ili daju tek oskudne podatke. No, držimo da se - spajajući sitne, razasute informacije - može ukazati na važnost koje su ove žene imale u životu gradske zajednice. ${ }^{4}$

Kada govorimo o položaju pripadnica gradečke elite, treba imati na umu da su žene u cjelini u Gradecu uživale relativno povoljan položaj. ${ }^{5}$ Bile su izjednačene u imovinskim pravima, gospodarski aktivne, a njihov je rad bio važan kako za obitelj, tako i za širu zajednicu. I u slučajevima kada su bile u braku, samostalno su prodavale i kupovale nekretnine, vodile poslove, a zanimanja kojima su se bavile u nekim su se slučajevima razlikovala od onih kojima su se bavili njihovi muževi, što je još jedan pokazatelj njihove nezavisnosti na gospodarskome planu. Ravnopravnost su uživale i na sudu gdje ih nalazimo u svim ulogama (tužitelja, tuženoga i svjedoka) i u svim vrstama parnica. Nezavisno od muževa bile su i nositeljice

men and Power in East Central Europe - Medieval and Modern, ur. Marianne Sághy, East Central Europe 20-23/1 (1993-1996), 171-172.

2 Usp., na primjer, Shulamith Shahar, The Fourth Estate. A history of women in the Middle Ages (London; New York: Routledge, 1996).

3 O sličnim istraživanjima na primjeru engleskih gradova vidi: Charlotte Carpenter, “The Formation of Urban Élites: Civic Officials in Late-Medieval York 1476-1525” (doktorski rad, University of York, 2000), 17-18. Posebnu pozornost ulozi žena u formiranju gradske elite i prijenosu društvenoga statusa u svome je radu poklonila napose Jenny Kermode, "Sentiment and Survival: Family and Friends in Late Medieval English Towns”, Journal of Family History 24 (1999), br. 1: 5-18. O ulozi žena u političkom životu u sjevernim, napose njemačkim gradovima vidi: Marta C. Howell, "Citizenship and Gender: Women Political Status in Northern Medieval Cities", u: Women and Power in the Middle Ages, uredile Mary Erler i Maryanne Kowaleski (Athens; London: The University of Georgia Press, 1988), 37-60.

4 Gradečka vrela objavljena su u: Ivan Krstitelj Tkalčić, Povjestni spomenici slob. kralj. grada Zagreba. Monumenta historica liberae regiae civitatis Zagrabiae, sv. 1-11 (Zagreb: Grad Zagreb, 1889-1905) (dalje: MCZ).

5 Žene su aktivno sudjelovale u gospodarskom i društvenom životu i u gradovima u drugim dijelovima Europe. Za danske gradove usp., na primjer, Grethe Jacobsen, "Kirstine Buddes, Else Wessels und eine unbekannte Sattlerwitwe - dänische Städtebgerinnen im 15/16. Jahrhundert”, u: Fürstinnen und Städterinnen. Frauen im Mittelalter, uredili Gerald Beyreuther, Barbara Pätzold i Erika Uitz (Freiburg; Basel; Wien: Herder, 1993), 142-163. 
civiteta. ${ }^{6}$ No, iako su uživale druga građanska prava, građanke nisu mogle birati ni biti birane za članove magistrata, čime su im bila uskraćena politička prava, a to je ograničenje vrijedilo, kao što smo već napomenuli, i za pripadnice elite. ${ }^{7}$

Ipak, iako ne sudjeluju direktno u gradskoj vlasti, pripadnice elite bile su usko povezane s njezinim nositeljima te tako posredno utjecale na upravljanje gradom. Njihova uloga bila je posebno važna u stvaranju mreža koje su povezivale vodeće obitelji i pojedince, a što možemo vidjeti i iz primjera koji slijede.

Jedna od pripadnica gradečke elite bila je Franciska, kći Gyana, sina Donata de Medzo. ${ }^{8}$ Njezin je stric bio Petar Donati, gradski sudac 1368. godine, ${ }^{9}$ a o njezinoj pripadnosti vodećemu sloju unutar gradskoga društva svjedoče i njezini brakovi. ${ }^{10}$ Franciska je, naime, prvo bila supruga Filipa, Maurova sina, vijećnika "latinskog jezika" u gradskome magistratu, ${ }^{11}$ s kojim je imala sina Žigmunda, ${ }^{12}$ a potom, nakon

\footnotetext{
6 Stanovništvo Gradeca dijelilo se na građane (cives), stanovnike (inhabitatores) i stanare (inquilini). Građani su uživali gospodarske i druge povlastice koje je kralj podijelio gradu, birali su gradski magistrat te su mogli biti izabrani za njegove članove, a kao vijeće tota communitas donosili su sve važne odluke grada. Druge dvije skupine nisu uživale navedena prava. Sve tri kategorije stanovništva bile su podvrgnute jurisdikciji gradskog suca. Više o različitim kategorijama stanovništva u Gradecu vidi u: Nada Klaić, Zagreb u srednjem vijeku (Zagreb: Sveučilišna naklada Liber, 1982), 216-220; Magdalena Apostolova Maršavelski, Iz pravne prošlosti Zagreba (13.-16. stoljeće) (Zagreb: Školska knjiga, 1998), 161-172.

7 O položaju žena u gradskim naseljima srednjovjekovne Slavonije vidi: Marija Karbić, "'Nije, naime, njezina duša drugačija nego kod muškarca' - položaj žene u gradskim naseljima međurječja Save i Drave u razvijenom i kasnom srednjem vijeku", u: Žene u Hrvatskoj. Ženska i kulturna povijest, uredila Andrea Feldman (Zagreb: Institut Vlado Gotovac; Ženska infoteka, 2004), 57-76; Ista, "The Role of Women in the Economic Life of Medieval Slavonian Towns as Reflected in Urban Legislation and Everyday Life", u: East meets West: A Gendered View of Legal Tradition. Sixth Conference of the International Research Nerwork "Gender Differences in the History of European Legal Cultures", Budapest March 10th - 12th 2011, uredile Grethe Jacobsen i Heide Wunder (Kiel: Solivagus Verlag 2015), 130-140; Ista, "Women and Property in Medieval Slavonian Towns", u: Towns and Cities of the Croatian Middle Ages: Authority and Property, uredile Irena Benyovsky Latin i Zrinka Pešorda Vardić (Zagreb: Hrvatski institut za povijest, 2014), 439-454.

8 Franciska se kao kći Gyana, sina Donata de Medzo spominje u više dokumenata. Usp. MCZ, sv. 6: 87; sv. 9: 91, 347.

9 MCZ, sv. 11: 237.

${ }^{10}$ Pripadnici obitelji iz koje je Franciska potekla živjeli su na Gradecu sredinom i u drugoj polovini 14. stoljeća. Uz Franciskina oca Gyana i strica Petra ondje nalazimo i njihova brata Marka. Usp., npr., MCZ, sv. 4: 101. O ovoj obitelji vidi: Vladimir Bedenko, "Društvo i prostor srednjovjekovnoga Gradeca", u: Zagrebački Gradec 1242. - 1850., ur. Ivan Kampuš, Lujo Margetić i Franjo Šanjek (Zagreb: Grad Zagreb, 1994), 44-45; Bruno Škreblin, "Uloga obiteljskih veza u formiranju gradske elite zagrebačkog Gradeca", Zbornik Odsjeka za povijesne znanosti Zavoda za povijesne i društvene znanosti HAZU 34 (2016): 46.

${ }^{11}$ Filip je bio veletrgovac i zabilježeno je da je prevezao čak 108 vagona robe preko Kupe, što je jedan od rijetkih izravnih podataka o trgovačkim aktivnostima gradečkih građana (MCZ, sv. 5: 162). Za vijećnika latinske skupine, iste skupine kojoj je pripadala i obitelj de Medzo, izabran je 1377. i 1382. godine (MCZ, sv. 5: 76, 159). U Gradecu je od 1377. godine bila provedena podjela magistrata "po jezicima." Svaka od četiri skupine (latinska, njemačka, mađarska i slavenska) imala je u magistratu po dva prisežnika i pet vijećnika, dok je sudac svake godine bio iz druge jezične skupine. O podjeli gradečkoga magistrata na jezike više vidi: Bruno Škreblin, "Etničke i političke skupine u srednjovjekovnom gradu. Primjer gradečkih lingui", Povijesni prilozi 35 (2008): 91-148 i ondje navedenu literaturu. God. 1384. Filip je već preminuo jer se Franciska spominje kao njegova udovica ( $M C Z$, sv. 9:2). U $M C Z$, sv. 9: 15 Filip se pogrešno navodi kao Markov, a ne Maurov sin, no drugi njegovi spomeni u vrelima potvrđuju da je bio Maurov sin. Usp. i: Vladimir Bedenko, Zagrebački Gradec. Kuća i grad u srednjem vijeku (Zagreb: Školska knjiga, 1989), 44.

${ }^{12}$ MCZ, sv. 6: 87.
} 
njegove smrti krajem 14. stoljeća, supruga Ivana Gracina, koji je obnašao dužnost prisežnika ${ }^{13}$ i s kojim je imala kćeri Maricu i Luciju ${ }^{14}$ Prisežnik je bio i Franciskin sin iz prvoga braka Žigmund. ${ }^{15}$ Njezina kći Lucija bila je, pak, udana za Ivana Zigetšaka, suca, ${ }^{16}$ a nakon njegove smrti preudaje se za Mihaela, Andrijina sina, koji je bio sudac u Božjakovini. ${ }^{17}$ Spomenimo još i da je kći Franciskina muža Ivana Gracina iz ranijega braka - Elizabeta bila udana za Petra (Peterkona), sina Grgura Angelijeva, prisežnika iz mađarske skupine. ${ }^{18}$ Može se još ukazati i na sestru Franciskina zeta Ivana Zigetšaka - Ceciliju, koja je imala dva sina iz dva braka, oba članove magistrata - s Gallom je imala sina Petra zvanoga Penter, jurata, a s juratom Mihaelom Ortphom (Ortophlichem) Stjepana, suca iz 1433. godine. ${ }^{19}$ Sve to pokazuje isprepletenost rodbinskih veza između pripadnika gradske elite, pogotovo ako se uzme u obzir da je i sljedeća ugledna građanka o kojoj ćemo nešto reći također bila povezana s obitelji Donati.

Riječ je o Katarini, supruzi Franciskina sina Žigmunda, o čijemu se obiteljskom podrijetlu, nažalost, ništa ne može reći, ali svakako se također radi o vrlo bogatoj i uglednoj građanki iz prve polovice 15. stoljeća. Nakon što, ostavivši zajedničku kćer Margaretu, umire njezin prvi muž Žigmund, ${ }^{20}$ Katarina se potom udala za Petra Šafara, koji je dotad već dva puta bio sudac iz njemačke skupine. ${ }^{21}$ Njezin brak s

${ }^{13}$ Franciska se kao Ivanova žena spominje 1387. godine (MCZ, sv. 9: 33), a kao udovica 1400. godine ( $M C Z$, sv. 9: 115). Ivan Gracin spominje se kao prisežnik 1384. godine (MCZ, sv. 9: 3). Mrtav je 1400. godine $(M C Z$, sv. 9: 113, 115). Prisežnici (jurati) su bili zaprisegnuti građani koji pomažu sucu pri suđenju, a mogu i suditi u manjim sporovima. Zapravo obavljaju glavne tekuće poslove u gradu. Zajedno $s$ njima gradski su magistrat činili vijećnici (consiliarii), koji su obavljali savjetodavnu funkciju i nadzirali rad suca i prisežnika. Usp. Škreblin, "Etničke i političke", 95.

${ }^{14}$ Lucija se kao Franciskina kći spominje u $M C Z$, sv. 6: 87, a kao kći Ivana Gracina u MCZ, sv. 6: 128. Marica se kao Franciskina i Ivanova kći spominje u dokumentu koji svjedoči o zamjeni nekih zemljišta između nje i Franciske ( $M C Z$, sv. 9: 350). Iz ovoga dokumenta saznajemo i da je Maričin muž bio Andrija Antunov. Nažalost, ne znamo kada je spomenuta zamjena izvršena.

${ }_{15}$ Žigmund se kao prisežnik (iuratus) u vrelima spominje 1414. godine, a kao vijećnik (consiliarius) 1413. i 1416. godine ( $M C Z$, sv. 6: 5, 15, 30). Mrtav je već 1417. godine. Za funkcije koje je Žigmund obnašao usporedi i: Škreblin, "Etničke i političke”, 140. Treba upozoriti da je Žigmund dužnost prisežnika vršio i prije 1414. godine jer se 1413. u popisu vijećnika navodi kao Sigismundus iuratus. No, budući da popisi dužnosnika za prethodno razdoblje nisu sačuvani, nemamo za to direktne potvrde u izvorima.

${ }^{16} M C Z$, sv. 6: 87, 127-128; sv. 9: 226. Lucija se kao udovica Ivana Zigetšaka spominje 1429. godine kada prodaje neke oranice prope locum cremacionis maleficarum vulgo Zredische dictum (MCZ, sv. 9: 171). Ivan je bio sudac 1420. (MCZ, sv. 6: 82).

${ }_{17}$ MCZ, sv. 6: 156-157, 159-160; sv. 9: 226, 253. Mihael se u izvorima spominje i kao successor Johannis Zygetshak (MCZ, sv. 6: 143-144).

${ }^{18} M C Z$, sv. 6: 157-158. Za Elizabetu vidi i: $M C Z$, sv. 9:107.

${ }_{19}$ Usp. $M C Z$, sv. 6: 157, 278; sv. 9: 159, 237, 253.

${ }^{20}$ Kao Žigmundova udovica Katarina se spominje 20. listopada 1416. (MCZ, sv. 6: 35). Margareta se kao Žigmundova kći spominje, npr., u $M C Z$, sv. 6: 217, a kao Katarinina, osim na drugim mjestima, i u $M C Z$, sv. 9: 300 .

${ }^{21}$ O obitelji Šafar i o Petru više vidi u: Bruno Škreblin, "Obitelj Šafar - iz života jedne njemačke obitelji”, Godišnjak njemačke zajednice - DG Jahrbuch 16 (2009): 83-100; Isti, "Njemački trgovci na srednjovjekovnom Gradecu", Godišnjak njemačke zajednice - DG Jahrbuch 20 (2013): 200-201. Petar je za suca biran 1405. (MCZ, sv. 2: 9, 12) i 1413. godine ( $M C Z$, sv. 6: 5). Nakon isteka sudačkoga mandata u magistratu nalazimo ga kao vijećnika 1414., 1416. i 1419. godine ( $M C Z$, sv. 6: 16, 29, 63). 
Petrom Šafarom sigurno je imao određenoga utjecaja da Margareta, njezina kći iz prvoga braka, sklopi brak s Jakovom, najmlađim sinom Petra Šafara. ${ }^{22}$ Katarinin treći muž Matija Farkaš, Egidijev sin, također je bio ugledni građanin, ali i pripadnik sitnoga plemstva iz Klokoča. ${ }^{23}$ Treba spomenuti da je i Katarinina sestra Elizabeta bila u braku s klokočkim plemićem Jurjem Maretićem. ${ }^{24}$ Veze Katarine i njezine obitelji s klokočkim plemićima, ali i Petrom Šafarom koji je također bio plemić, otvaraju mogućnost da je i sama njezina obitelj podrijetlom iz sitnoga plemstva.

Među uglednije gradečke građanke može se uvrstiti još jedna Katarina, koja je u trenutku kada ju prvi put susrećemo u vrelima već udovica Mihaela, sina Jurja Barbata, i supruga Sebastijana Soldinara. ${ }^{25}$ Sebastijan se spominje kao vijećnik, dakle može se uvrstiti u uglednije i utjecajnije građane. ${ }^{26}$ Međutim, Katarina je i drugi put ostala udovica, a njezin treći muž bio je Antun Roth iz Nürnberga. ${ }^{27}$ On postaje prisežnik 1456. godine, a u popisu magistrata tom je prilikom naveden kao Anthonius successor Soldynar. ${ }^{28}$ Katarinin sin iz njezina braka sa Sebastijanom, Ivan Soldinar, bio je jedan od uglednijih građana u drugoj polovici 15. stoljeća te je dva puta bio gradski sudac (1477. i 1483.). ${ }^{29}$

Ugledne građanke bile su i dvije Margarete, supruga i kći prisežnika Brcka ribara, sina Ivana iz Ivanje Reke. ${ }^{30}$ Brckova supruga Margareta bila je nakon njegove smrti u braku sa sucem Jakovom Eberspeckom te vijećnikom i prisežnikom Akacijem, ${ }^{31}$ dok je suprug Brckove kćeri Margarete bio sudac Benedikt, Mihaelov sin. ${ }^{32}$

\footnotetext{
${ }^{22}$ Margareta se kao Jakovljeva supruga spominje 1435. godine, npr., u MCZ, sv. 6: 217.

${ }^{23}$ Katarinin brak s Matijom Farkašem spominje se na više mjesta. Usp., npr., $M C Z$, sv. 6: 128; sv. 9: 300. O plemićima iz Klokoča i njihovoj prisutnosti na Gradecu vidi: Bruno Škreblin, "Pripadnici plemićke zajednice iz Klokoča na zagrebačkom Gradecu u 15. stoljeću: Primjer uloge sitnog plemstva u formiranju urbanih elita", u: Ascendere historiam. Zbornik u čast Milana Kruheka, uredili Marija Karbić, Hrvoje Kekez, Ana Novak i Zorislav Horvat (Zagreb: Hrvatski institut za povijest, 2014), 67-80. O Matiji Farkašu napose: Isto, 73-74.

${ }^{24}$ Juraj Maretić istaknuti je pripadnik skupine Klokočana na Gradecu. Godine 1451. bio je i plemićki sudac Zagrebačke županije. U Gradecu je obnašao dužnost vijećnika. Usp.: Škreblin, "Pripadnici plemićke zajednice", 74-75.

${ }^{25}$ MCZ, sv. 10: 7 (1441.).

${ }^{26}$ Sebastijan se spominje kao vijećnik 1441. godine ( $M C Z$, sv. 6: 342).

${ }^{27} M C Z$, sv. 10: 167. O Antunu više vidi u: Bruno Škreblin, "Nijemci na Gradecu sredinom i u drugoj polovini 15. stoljeća", Godišnjak njemačke zajednice - DG Jahrbuch 17 (2010): 49-51; Isti, "Njemački trgovci", 202-203.

${ }^{28} M C Z$, sv. 7: 104.

${ }^{29}$ MCZ, sv. 7: 458; sv. 8: 23.

${ }^{30} M C Z$, sv. 10: 69, 71. Ribar Brcko izabran je za vijećnika 1437. godine (MCZ, sv. 6: 267). Godine 1446. je već preminuo, a navodi se i da je bio prisežnik te da je sin Ivana iz Ivanje Reke ( $M C Z$, sv. 10: 71).

${ }^{31}$ Kao Jakovljeva supruga i Brckova udovica Margareta se u vrelima javlja 1449. godine (MCZ, sv. 10: 105), a kao Jakovljeva udovica 1455. godine ( $M C Z$, sv. 10: 163). Jakov Eberspeck bio je prisežnik 1448. godine, a sudac 1450. i 1452. godine ( $M C Z$, sv. 6: 453; sv. 7: 1,32). Moguće je da je, iako se u vrelima to izravno ne navodi, bio plemić. O Eberspecku vidi: Škreblin, "Nijemci u Gradecu", 47-49. Akacije se u magistratu prvi put javlja 1457. godine kao vijećnik ( $M C Z$, sv. 7: 121). Kao prisežnik javlja se 1459. godine ( $M C Z$, sv. 7: 169). Godine 1461. već je preminuo jer se Margareta navodi kao njegova udovica ( $M C Z$, sv. 10: 208).

${ }^{32}$ Margareta i Benedikt bili su u braku već 1432. godine jer se Benedikt tada spominje kao zet Brcka ribara (MCZ, sv. 9: 235). Kao Benediktova supruga Margareta se javlja i 1446. godine. U tome se doku-
} 
Ove građanke izdvojili smo jer je o njima sačuvano nešto više podataka u izvorima, ali, naravno, postoje i drugi primjeri bogatih i utjecajnih građanki. Svakako da među važnije od njih možemo ubrojiti i Reginu, kći Gerina de Spinala, pripadnicu obitelji koja je igrala važnu ulogu sredinom 14. stoljeća. ${ }^{33}$ Njezin muž bio je Luka Bonioli, jedan od najuglednijih građana krajem 14. stoljeća, koji je dva puta obnašao i dužnost suca. ${ }^{34}$ Njihova kćer Benicha bila je, pak, udana za firentinskoga trgovca Ciona, sina Ivanova, koji je najmanje četiri puta bio gradski sudac. ${ }^{35}$

Vrela nam svjedoče i o četiri sestre, kćeri suca Mihaela i unuke suca Sebastijana, koje su redom udavane za suce ili prisežnike: Katarina za prisežnika Leonarda, sina Henrika iz Bavarske, Magdalena (ili Jelena) za suca Valentina Šaronića, Uršula za Pavla zlatara iz Kyus Jenowa, ${ }^{36}$ gradskoga suca 1478. i 1484. godine, a Barbara prvo za prisežnika i zlatara Benedikta iz Baranje, a kasnije za bivšega gradskog suca Tomu Horvatina. ${ }^{37}$ Više kćeri imao je i Ivan Perović, potomak firentinske trgovačke obitelji. Neki od njegovih zetova bili su sitni plemići iz Svetačja i Klokoča. ${ }^{38}$ Ugledna građanka bila je i Katarina, kći suca Blaža, Pavlova sina, prvo udana za prisežnika i štacunara Matiju, ${ }^{39}$ sina Lodovikova, a potom za suca Blaža, sina Lazara iz Iloka. ${ }^{40}$

Ovdje navedeni primjeri svjedoče nam da su pripadnice gradske elite sklapale brakove poglavito unutar svoga društvenog sloja te koliko su istaknute obitelji i pojedinci bili povezani upravo preko ženidbenih veza. ${ }^{41}$ No, isto tako treba reći da je u mnogim slučajevima upravo brak s uglednom i bogatom građankom omogućio društveni uspon pojedinca ili mu barem pritom pomogao. O tome nam svjedoče primjeri poput onoga Luke Boniola i Ciona Ivanova, supruga Lukine kćeri Beniche, te Brcka ribara i suca Benedikta, supruga Brckove kćeri Margarete, u kojima je zet suca ili prisežnika postao sucem, ${ }^{42}$ ali i slučajevi u kojima bi novi

mentu spominju i njihova djeca ( $M C Z$, sv. 10: 69). Iste godine Benedikt je i umro (MCZ, sv. 10: 71). Za suca je Benedikt bio izabran 1443. godine ( $M C Z$, sv. 6: 380).

${ }^{33}$ O ovoj obitelji vidi: Škreblin, "Uloga obiteljskih veza”, 45.

${ }^{34}$ MCZ, sv. 9: 11. Luka je sudac bio 1380. i 1388. (MCZ, sv. 1: 279; sv. 5: 287).

${ }^{35}$ Usp. Bruno Škreblin, “Urbana elita zagrebačkog Gradeca u 15. i početkom 16. st. Primjeri nekolicine uglednih gradečkih građana”, u: Mestne elite v srednjem in zgodnjem novem veku med Alpami, Jadranom in Panonskom nižinom / Urban elites in the Middle Ages and the Early Modern Times between the Alps, the Adriatic and the Pannonian Plain, ur. Janez Mlinar i Bojan Balkovec, Zbirka Zgodovinskega časopisa 42 (Ljubljana: Zveza zgodovinskih društev Slovenije, 2011), 311-314.

36 Kisjenő, današnji Chișineu u zapadnoj Rumunjskoj.

37 Škreblin, "Uloga obiteljskih veza”, 48.

38 Škreblin, "Pripadnici plemićke zajednice”, 76; Isti, "Uloga obiteljskih veza”, 47-48.

39 Štacunar je trgovac na malo, koji je držao trgovinu u gradu.

${ }^{40}$ O Katarini i njezinoj obitelji vidi: Škreblin, "Uloga obiteljskih veza”, 50-51.

${ }^{41}$ Brakovi među pripadnicima elite karakteristični su i za gradove u drugim dijelovima Europe. Za Exeter, Norwich i York u Engleskoj usp. Carpenter, “The Formation”, 135-136.

${ }^{42}$ Osim ranije navedenih takvih primjera postoje i brojni drugi. Ovdje možemo još spomenuti, na primjer, suca Ivana Vasasa, zeta suca Mikeča Henčova, te suca Matiju krojača, zeta suca Andrije Šimunića. Usp. Škreblin, "Uloga obiteljskih veza”, 52. 
muž udovice člana magistrata i sam postao njegovim članom. Ovi potonji zapravo još više ukazuju na značenje koje su u prijenosu društvenoga ugleda imale žene. Brakom s udovicom, a često i s imovinom koju bi mu darovala, a o čemu će još biti riječi, pojedinac bi preuzeo i položaj u društvu koji je ranije pripadao pokojnome mužu. U nekim slučajevima način na koji se pojedinci navode u izvorima neposredno to i pokazuje. Tako je Akacije, treći suprug Margarete, udovice Brcka ribara i udovice Jakova Eberspecka, u popisu članova magistrata godine 1457. naveden kao Achaczius successor Eberspeck. ${ }^{43}$ Već ranije smo spomenuli da je Antun Roth, suprug Katarine, udovice Sebastijana Soldinara, u popisu magistrata godine 1456. naveden kao Anthonius successor Soldynar. ${ }^{44}$

Važnost ženidbenih veza napose je vidljiva, kao što svjedočei primjeri Eberspecka, Rotha, Ciona, ali i brojnih drugih, u slučajevima došljaka koji su ubrzo nakon što su se oženili nekom uglednom građankom postali članovi magistrata. Naravno, vjerojatno je da su oni već i u vrijeme dolaska u grad bili imućniji (Građani su težili ženidbeno se povezivati u istome statusnom krugu.) kao i da su imali sposobnosti i ambicija, ali ženidbeno povezivanje s uglednom građankom ili udovicom značilo je njihovu punu integraciju u gradsku elitu. Ipak, treba reći da je i povezivanje brakom već afirmiranih pojedinaca i obitelji također imalo važnost za učvršćivanje njihova položaja u društvu. Takvo povezivanje, poput onoga Petra Šafara i Katarine, Žigmundove udovice, također je povećavalo ugled i materijalnu snagu pojedinca pa se to može promatrati kao jedan od načina konsolidacije gradske elite. ${ }^{45}$

Značenje afinatskih veza u formiranju gradske elite pokazuje i podatak da su od obiteljskih ili ženidbenih veze, koje se mogu utvrditi između sudaca i članova magistrata u razdoblju od 1352. do 1525. godine, ženidbene ili afinatske dva do tri puta češće nego patrilinearne. ${ }^{46}$ Razlozi zašto su afinatske veze imale veliku važnost mogu biti višestruki. ${ }^{47} \mathrm{U}$ nekim se slučajevima vjerojatno radilo o ne-

\footnotetext{
${ }^{43}$ MCZ, sv. 7: 121.

${ }^{44}$ MCZ, sv. 7: 104.

45 Sličnu situaciju nalazimo i u gradovima u Transilvaniji. O ženidbenim strategijama pripadnika tamošnjih gradskih elita i njihovu utjecaju na političku karijeru i prijenos imovine vidi: Ágnes Flóra, “From decent stock': Generations in Urban Politics in Sixteenth-Century Transilvania”, u: Generations in Towns: Succession and Success in Pre-Industrial Urban Societies, uredili Finn-Einar Eliassen i Katalin Szende (Newcastle upon Tyne: Cambridge Scholars Publishing, 2009), 223-226.

${ }^{46}$ Usp. Škreblin, "Uloga obiteljskih veza”, 52. Na relativno maleni broj patrilinearnih veza među gradskim dužnosnicima nailazimo i u gradovima u drugim dijelovima Europe. Važnost afinatskih veza potvrđena je i u gradskim elitama danskih i norveških gradova, doduše u nešto kasnijem periodu. Usp. Finn-Einar Eliassen, "The Son-in-Law Principle: Dynasties in Government and Trades in Early Modern Danish and Norwegian Towns", u: Generations in Towns: Succession and Success in Pre-Industrial Urban Societies, uredili Finn-Einar Eliassen i Katalin Szende (Newcastle upon Tyne: Cambridge Scholars Publishing, 2009), 257-281. Istraživanja Charlotte Carpenter pokazala su da se za relativno maleni broj gradskih službenika u Yorku može utvrditi postojanje patrilineranih veza (Carpenter, “The Formation”, 133).

${ }^{47}$ Prema istraživanjima provedenima u engleskim gradovima neki od mogućih razloga slabljenja patrilinealnoga obrasca su, između ostaloga, visoka stopa smrtnosti, problemi s akumulacijom i transferom kapitala te odlazak iz grada (Carpenter, “The Formation”, 133).
} 
postojanju muških potomaka. U nedostatku sinova zetovi preuzimaju njihovu funkciju i omogućavaju nastavak života obitelji uključujući i očuvanje njezina društvenog utjecaja u budućnosti. Povezivanje supruga uz ženinu obitelj išlo je ponekad dotle da su oni preuzimali i prezime obitelji iz koje je supruga potekla. Luka Bonioli preuzeo je tako prezime svoga tasta, oca svoje prve žene, prisežnika Marka Boniolija. ${ }^{48}$ Pritom treba naglasiti da su takvi brakovi bili obostrano korisni - i zetovima, kojima omogućuju uspon u društvu, i obitelji koja na taj način opstaje. ${ }^{49}$ Drugi razlog za podupiranje rođaka preko braka može ležati u činjenici da su oni bili sposobniji i ambiciozniji od krvnih srodnika te tako opet korisniji za obitelj. Sinovi Mihaela Sebastijanova: Benedikt, Marko i Juraj bili su članovi magistrata, ali nikad nisu postali suci, dok trojica njegovih zetova jesu (Valentin Šaronić, Pavao Zlatar i Toma Horvatin).

Jedan od mogućih razloga za podupiranje zetova može biti i jača emocionalna veza kćeri i očeva. Nažalost, naša nam vrela ne omogućavaju reći nešto više o tome. Ipak, pojedini podaci posredno nam svjedoče o posebnoj brizi očeva za kćeri. Tako je, na primjer, sudac Blaž svoju palaču ostavio kćerima, iako je imao i sinove, te bi u skladu s nasljednim pravom u Gradecu bilo očekivano da ju podijeli među svom djecom jednako. ${ }^{50}$

Društveni položaj pripadnica gradske elite bio je povezan i sa znatnim imutkom kojim su raspolagale, a zanimljivo je vidjeti i na koje su ga načine, napose kada je riječ o nekretninama, stekle kao i kako su dalje posredovale u njihovu transferu, a na što ćemo se osvrnuti kasnije.

Treba napomenuti da se putovi na koje su nekretnine dolazile u njihove ruke nisu razlikovali od onih na koji su do vlasništva nad nekretninama dolazile druge stanovnice Gradeca. U prvome redu žene su do nekretnina dolazile nasljedstvom - i to kako od roditelja, tako i od supruga, ali i od braće, djece, rođaka. Osim toga, žene su do nekretnina mogle doći putem darovanja, bilo od strane roditelja, supruga, rođaka ili drugih osoba, a mogle su ih dobiti i na ime miraza ili steći kupovinom ili zamjenom. ${ }^{51}$

Različite primjere stjecanja nekretnina susrećemo i u slučajevima pripadnica elite kojima se u ovome radu bavimo. Prateći njihove sudbine možemo dobro uočiti osobitosti nasljednoga prava na Gradecu i načine na koji su žene bile uključene u promet nekretninama. No, prije nego prijeđemo na konkretne primjere, evo samo nekoliko osnovnih napomena o sustavu nasljeđivanja u Gradecu. Prvo, ondje su ženska djeca bila izjednačena s muškom djecom u nasljednim pravima,

\footnotetext{
48 Škreblin, "Uloga obiteljskih veza”, 45.

49 Usp. Carpenter, “The Formation”, 151.

${ }^{50} \mathrm{MCZ}$, sv. 10: 170. O nasljednome pravu bit će riječi dalje u tekstu.

${ }^{51}$ O načinima na koje su žene mogle doći u posjed nekretnina na Gradecu vidi: Karbić, "Women and Property", 441-451.
} 
što je u skladu s odredbama tavernikalnoga prava, to jest prava koje je vrijedilo u gradovima kojima je prizivna sudska instanca bio sud kraljeva magistra tavernika, prema kojima su također nasljednici prvoga reda djeca oba spola. ${ }^{52}$ I u gradečkoj praksi i prema odredbama tavernikalnoga prava supruga, ako je imala djecu s ostaviteljem, bila je zajedno s njima nasljednik prvoga reda. ${ }^{53}$ Što se tiče nasljednoga prava žene ili točnije, s obzirom na izjednačenost muškaraca i žena u imovinskim pravima, preživjeloga supružnika u braku bez djece, u historiografiji postoje različita mišljenja (Od onoga da je i u tome slučaju preživjeli supružnik bio nasljednik prvoga reda do onoga da je tada poštovano načelo paterna paternis, materna maternis, to jest da se imovina preminuloga supružnika vraćala obitelji iz koje je potekla ako se preminuli supružnik oporukom nije očitovao u korist preživjeloga.), ${ }^{54}$ a u izvorima nalazimo potvrde i za jednu i za drugu tezu. Neke od građanki kojima se ovaj put bavimo također su doživjele smrt supruga s kojim nisu imale djece te su bile suočene s pitanjem prava na nasljeđivanje njegove imovine pa ćemo se na ovu temu još vratiti.

Važnost nasljedstva za imovinski položaj pripadnica gradske elite očit je i u slučaju Franciske Donati. Godine 1379. Franciska je zajedno s Ivanom, sinom Mihaela zvanoga Vitez, naslijedila sve posjede pokojnoga Donata, svoga djeda. ${ }^{55} \mathrm{U}$ kakvom su srodstvu bili Franciska i Ivan, tom prilikom nije izravno rečeno, no vjerojatno su bili bratići. ${ }^{56} \mathrm{U}$ trenutku kada su Franciska i Ivan naslijedili Donato-

\footnotetext{
${ }^{52}$ O nasljednim pravima djece na Gradecu vidi: Lujo Margetić, Hrvatsko srednjovjekovno obiteljsko i nasljedno pravo (Zagreb: Narodne novine, 1996), 286-288, 321-324, 327-335; Apostolova Maršavelski, Iz pravne prošlosti, 13-137. Ovdje treba napomenuti da Apostolova Maršavelski smatra da je na zagrebačkome Gradecu do izjednačenosti muške i ženske djece u pravu nasljeđivanja došlo tijekom 14. i 15. stoljeća, a da su prema odredbama gradečkoga privilegija (Zlatne bule) prednost imali sinovi, dok su kćeri i žena nasljeđivale tek u slučaju kada ostavitelj nije imao sinova. Opširnije o tavernikalnome pravu i tavernikalnim gradovima te Iločkome statutu kao izvoru za to pravo vidi: Štefánia Mertanová, Ius tavernicale: stúdie o procese formovania práva taverníckych miest v etapách vývoja taverniíckeho súdu $v$ Uhorsku (15.-17. stor.) (Bratislava: Slovenskej Akademie Vied, 1985); Lujo Margetić, "Iločka pravna knjiga (tzv. Iločki statut)", Zbornik Pravnog fakulteta u Zagrebu 44 (1994), br. 1-2: 93-116; Darko Vitek, "Struktura i izvorište teksta Iločkog statuta", Scrinia Slavonica 1 (2001): 404-420. Vidi i: Karbić, "Nije, naime, njezina duša”, 57 i ondje navedenu literaturu. Iločki statut objavljen je u: Rudolf Schmidt, Statut grada Iloka iz godine 1525. (dalje: Iločki statut), Monumenta historico-juridica Slavorum Meridionalium, vol. 12. (Zagreb: JAZU: 1938).

${ }_{53}$ Apostolova Maršavelski, Iz pravne prošlosti, 135; Margetić, Hrvatsko srednjovjekovno obiteljsko, 287288.

${ }^{54}$ Usp. Karbić, "Women and Property", 443-444 i ondje navedenu literaturu. Pritom treba imati na umu da je, za razliku od Gradeca u kojemu u praksi nije postojalo razlikovanje nasljednih i stečenih dobara, tavernikalno pravo tu razliku poznavalo. Žene i djeca nasljeđivali su nasljedna dobra, dok je, što se tiče raspolaganja stečenim, ostavitelj imao slobodne ruke (Iločki statut, knj. I, gl. 7, 19; knj. IV, gl. 2, 65; Margetić, Hrvatsko srednjovjekovno obiteljsko, 287-288).

${ }^{55}$ MCZ, sv. 9: 15. U gradske knjige upisano 1384. godine.

${ }^{56} \mathrm{Na}$ jednome mjestu u gradskim knjigama navodi se da je Ivan bio Franciskin brat (MCZ, sv. 5: 279280 ), no to nije moguće. Očevi su im različiti, a ni majka im ne može biti ista. Naime, Ivan je s Donatom, budući da s njime nije bio povezan preko oca, morao biti povezan preko majke. Ako uzmemo u obzir na Gradecu vladajuće jednako nasljedno pravo muških i ženskih potomaka, čini nam se najvjerojatnijim
} 
ve posjede, vjerojatno su bila pokojna sva Donatova djeca te su ih stoga naslijedili unuci. O povezanosti i srodstvu Franciske i Ivana svjedoči i činjenica da joj je Ivan 1387. godine ostavio testamentaliter i iure perhempnali sve svoje posjede. ${ }^{57}$ Potvrdu vlasništva nad posjedima koje je naslijedila od Donata, Franciska je dobila okončanjem parnice s pavlinima iste godine.$^{58}$ Krajem 14. stoljeća u Franciskinim se rukama nalazila i najveća parcela unutar gradskih zidina. Ta se parcela nalazila sa sjeverne strane do Kamenitih vrata, zauzimala je prostor veličine pet kurija, a na njoj su se nalazile palača, kula, trgovine i kapela Sv. Uršule. Taj je posjed prije pripadao njezinome stricu Petru, a činjenica da je na kraju postao isključivim Franciskinim vlasništvom pokazuje da drugih nasljednika nije bilo. ${ }^{59}$ Tako i slučaj obitelji de Medzo pokazuje koliko su srednjovjekovne obitelji bile krhke. Iako je Donat imao barem trojicu sinova i jednu kćer, na kraju se loza, i to po ženskoj liniji, nastavila samo preko Franciske, kojoj su i pripali obiteljski posjedi.

Slučajevi pripadnica elite o kojima je riječ pružaju nam i potvrdu prakse da su supruge u braku u kojemu je bilo djece nasljeđivale zajedno s djecom. Franciskina snaha Katarina, supruga Franciskina sina Žigmunda, naslijedila je zajedno sa zajedničkom kćeri Margaretom brojne posjede: kuće, sjenike, vinograde, vrtove i zemlju s kmetovima. ${ }^{60}$

Imetak koji su Katarina i Margareta posjedovale bio je uistinu znatan. O tome saznajemo iz dokumenata koji bilježe podjelu imetka, do koje dolazi nakon što su neko vrijeme posjede držale zajednički, a koja nije izvršena odjednom nego u fazama. U podjeli provedenoj 1433. godine Margareti je pripao vinograd zvan Markovščak, neka zemlja sa stajom i vrt, a Katarini vinograd Kamenjak s pripadajućim zemljama i vrtom te pola jednoga drugog vinograda. ${ }^{61}$ Iste godine Katarina zajedno s kćeri Margaretom posjeduje i neki vinograd smješten u blizini gradskoga opkopa uz vinograd u vlasništvu crkve Sv. Marka. ${ }^{62}$ (Doduše, za njega saznajemo u trenutku kada ga prodaju.) Sljedeće godine Katarina i Margareta dijele zidane i drvene kuće s pripadajućim zemljištem i krušnom peći, vinograde, zemlje i vrtove sa stajama, zemlje i kmetska selišta u Pobrežju, selu blizu Save koje

\footnotetext{
da je Ivan bio sin neke po imenu nepoznate Donatove kćeri. U srednjemu vijeku i inače se bratom znao nazivati bratić pa i dalji rođak.

${ }^{57} M C Z$, sv. 9: 33. Res paraphernales bile su prema općemu ugarskom pravu poglavito stvari koje su žene dobile od svoje obitelji prilikom sklapanja braka. O tome pitanju više vidi dalje u tekstu.

${ }^{58}$ MCZ, sv. 9: 34 .

${ }^{59}$ Bedenko, "Društvo i prostor", 44-45. Petar se navodi kao vlasnik te kuće u popisu iz 1368. godine.

${ }^{60} M C Z$, sv. 6: 68. Potvrdu načela da je preživjeli supružnik zajedno s djecom nasljednik prvoga reda donosi nam i spor koji se vodio nakon smrti Katarinine kćeri Margarete (1439.). Njezin suprug Jakov Šafar sporio se oko njezine imovine s Matijom Farkašem, trećim mužem Margaretine majke Katarine, koji je nastupao u Katarinino ime. Naime, budući da Margareta nije sastavila oporuku, sud je odlučio da svi njezini posjedi i dobra pripadnu Jakovu i njihovoj djeci ( $M C Z$, sv. 6: 322).

${ }^{61} M C Z$, sv. 9: 245.

${ }^{62} M C Z$, sv. 9: 242.
} 
je bilo pod gradečkom jurisdikcijom, ${ }^{63}$ a ubrzo potom i međusobno zamjenjuju neke od posjeda koji su im pripali u podjeli, što nam omogućava da saznamo još neke pojedinosti o tim posjedima. Tada je Katarina dala Margareti svoje oranice kod crkve Sv. Margarete i vrt u podgrađu kod Mesničkih vrata kao i polovicu prihoda od jednoga vinograda, a Margareta njoj svoju polovinu palače u devetoj insuli s pripadajućim zemljištem i objektima te svoju polovinu nekih drvenih kuća. ${ }^{64}$ Godine 1435. Katarina i njezina kći ponovno između sebe dijele recte et equaliter kmetska selišta u Pobrežju, oranice u Pobrežju između potoka Borčena mlaka (Borchena mlaka) i potoka Tišice (Thysycza) kao i oranice zvane Delnice (Delnyce) i Srebrnica (Srebynnycze). ${ }^{65}$ Čini se da su se Katarina i Margareta odlučile na podjelu imetka kako bi sredile imovinske odnose u novim okolnostima koje su nastale nakon Katarinine treće udaje za Matiju Farkaša kao i zbog skore Margaretine udaje za Jakova Šafara. ${ }^{66}$ Činjenica da su Katarina i Margareta dotada držale svoju imovinu zajednički nije neobična, čak i ako ne uzmemo u obzir Margaretinu mladost. U vrelima nalazimo brojne primjere u gradskim naseljima srednjovjekovne Slavonije u kojima se radi o zajedničkome obiteljskom vlasništvu, ${ }^{67}$ a o njemu nam svjedoči i odredba Iločkoga statuta, koja određuje kako treba regulirati obrađivanje vinograda po nepodijeljenoj braći. ${ }^{68}$ Nepodijeljena imovina dovodila je do koncentracije kapitala, koja je olakšavala poslovanje, ali i pružala veću sigurnost članovima obitelji. ${ }^{69}$

Katarinina i Žigmundova kći Margareta, osim već spomenute imovine, raspolagala je i drugom imovinom. Naime, nakon smrti njezine rođakinje Salvagie ${ }^{70}$ pripalo joj je i pola kuće sa zemljištem i podrumom. Pritom je u odluci magistrata naglašeno da je Salvagia umrla bez oporuke te da stoga po gradskim običajima i slobodama imetak treba pripasti njezinome najbližem srodniku, to jest Margareti. ${ }^{71}$ Tako nam Margaretin slučaj pokazuje da su pripadnice elite imetak

${ }^{63}$ MCZ, sv. 9: 270.

${ }^{64} M C Z$, sv. 9: 271-272. Margareta se kao vlasnica vinograda i vrta kod Mesničkih vrata spominje i u MCZ, sv. 9: 286.

${ }^{65}$ MCZ, sv. 9: 278-279.

${ }^{66}$ Margareta se već u siječnju 1435. godine spominje kao žena Jakova Šafara (MCZ, sv. 6: 217), dok se u navedenim dokumentima datiranima 1434. godine o njoj još uvijek govori kao o neudanoj djevojci (domicella).

${ }^{67}$ Za Gradec vidi, npr., MCZ, sv. 10: 64-65; za Varaždin Josip Barbarić, Josip Kolanović, prir., Zapisnici poglavarstva slobodnog i kraljevskog grada Varaždina, sv. 3 (Varaždin: Historijski arhiv Varaždin, 1992), $172,201,252-253$.

${ }^{68}$ Iločki statut, knj. II, gl. 21, 35.

${ }^{69}$ Koncentracija kapitala jedan je od razloga za nastanak višestrukih obitelji. O povezanosti prisutnoga tipa obitelji i društvenih, gospodarskih i demografskih okolnosti na primjeru dalmatinskih gradova vidi: Zdenka Janeković Römer, Rod i grad: dubrovačka obitelj od XIII. do XV. stoljeća (Zagreb: HAZU, 1994), 22-54.

70 Vjerojatno se radi o inačici talijanskog imena Selvaggia.

${ }^{71}$ MCZ, sv. 6: 216-217. 
nasljeđivale ne samo od direktnih predaka nego i od rođaka. Da se pritom nije radilo samo o krvnim rođacima, nego i onima preko braka, svjedoči nam primjer Katarine, supruge Antuna Rotha, koja je naslijedila neka dobra svoga zeta, podstrigača sukna Demetrija. ${ }^{72}$

Na primjeru Katarine, udovice jurata Žigmunda, i njezine kćeri Margarete vidjeli smo da su supruge, ako je u braku bilo djece, zajedno s djecom nasljeđivale imovinu pokojnoga muža. Katarinin život, ali ovoga puta i razvoj situacije nakon smrti njezina drugog muža Petra Šafara, osvjetljava nam i pitanje što se događalo s udovicom ako u braku nije bilo djece, pogotovo ako je pokojni suprug imao djecu iz ranijega braka. Naime, nakon smrti Petra Šafara 1419. godine Katarina se sporila oko nasljeđa s trojicom Petrovih sinova iz prvoga braka (Andrijom, Petrom ili Perom zvanim Mox i Jakovom). Budući da je Katarina primila miraz od 26 florena, sud je ustvrdio (1420.) da ona nema pravo na ostalu imovinu koju je Petar ostavio svojim sinovima. ${ }^{73} \mathrm{Na}$ prvi pogled čini se da ovaj slučaj potvrđuje mišljenje Magdalene Apostolove Maršavelski da je u gradečkome nasljednom pravu prisutno načelo paterna paternis, materna maternis, to jest da se imovina preminuloga supružnika vraćala obitelji iz koje je potekla ako u braku nije bilo djece i ako se preminuli supružnik oporukom nije očitovao u korist preživjeloga. Udovičina prava bila su pritom ograničena samo na ono što je donijela u brak. ${ }^{74}$ No, ovaj slučaj treba ipak pažljivije promotriti te se osvrnuti na dvije stvari: miraz koji je Katarina primila i činjenicu da je Petar svoj imetak ostavio svojim sinovima.

U gradskim naseljima srednjovjekovne Slavonije postojao je institut miraza, ali on nije bio redovita pojava, nego se, sudeći po sačuvanim vrelima, javlja razmjerno rijetko. ${ }^{75}$ Miraz u srednjovjekovnim slavonskim gradovima pokazuje neke karakteristike zajedničke s onim u općemu ugarskom i slavonskom pravu, ali i neke bitne razlike prema njemu. Hrvatski pojam miraz zamjenjuje dva pojma koja se javljaju u izvorima, a to su dos i res paraphernales. Prema općemu ugarskom i slavonskom pravu, kako je ono bilo kodificirano u Tripartitu, ${ }^{76}$ dos je ženi plemića

\footnotetext{
${ }^{72}$ MCZ, sv. 7: 302, 307, 310 .

${ }^{73}$ MCZ, sv. 6: 45, 78-79, 81, 88, 92.

${ }^{74}$ Apostolova Maršavelski, Iz pravne prošlosti, 141, 121. Ova autorica smatra da je takva praksa bila logična zbog značenja koje su nekretnine, čije je posjedovanje bilo i jedan od uvjeta za stjecanje civiteta, a time i uključivanja u javni život zajednice, imale za život obitelji. Jednostavno, trebalo je spriječiti njihov prijelaz u tuđe ruke.

${ }^{75}$ Prema analizi agrarnoga poslovanja zabilježenoga u posjedovnim knjigama zagrebačkoga Gradeca ( $M C Z$, sv. 9-11), koju je izvršila L. Čoralić, darovanje zemlje u miraz čini samo 0,1 \% zemljišnoga poslovanja. Vidi: Lovorka Čoralić, "Zemljišni posjed i poslovanje građana Gradeca prema zemljišnim knjigama 14-15. stoljeća”, u: Zagrebački Gradec 1242. - 1850., uredili Ivan Kampuš, Lujo Margetić i Franjo Šanjek (Zagreb: Grad Zagreb, 1994), 120.

${ }^{76}$ Tripartit, zbornik pravnih odredbi koji je početkom 16. stoljeća sastavio István Verbőczy, predstavlja glavno vrelo za opće ugarsko srednjovjekovno pravo. Treba naglasiti da vrijednost Tripartita za istraživanje ugarskoga prava leži i u činjenici da su u njemu sadržane odredbe ugarskoga običajnog prava
} 
isplaćivan iz muževljeve imovine nakon njegove smrti, a kao naknada za gubitak nevinosti i zajednički život (propter eius deflorationem et concubitum). Dos se davao u novcu i pokretnoj imovini, a samo iznimno u nekretninama. U ovome potonjem slučaju nekretnine nisu prelazile u ženino vlasništvo nego su joj samo bile dane na uživanje. ${ }^{77}$ Dok je dos prema odredbama Tripartita bio, kako smo rekli, davan iz muževljeve imovine, res paraphernales su, prema općemu ugarskom i slavonskom pravu, stvari koje je žena povodom braka dobila od bilo koga (oca, majke, treće osobe ili kao uzdarje od strane muža) i koje su i u braku ostajale u njezinu vlasništvu te je njima slobodno raspolagala i za života i u smrti. ${ }^{78}$

U tavernikalnome pravu, kao i u općemu ugarskom i slavonskom pravu, dos žena dobiva iz muževljeve imovine, ali, za razliku od odredbi Tripartita, prema Iločkome statutu dos se nije ženi davao nakon muževljeve smrti nego ga je muž predavao prilikom sklapanja braka te je žena odmah imala puno vlasništvo nad imovinom koju je dobila kao dos. ${ }^{79}$ Osim toga, dos o kojemu govori Iločki statut čine nekretnine, a ne novac i pokretnine kao što je to bio slučaj kod dosa u općemu ugarskom i slavonskom pravu. Zanimljivo je napomenuti da se u Iločkome statutu o davanju miraza ne govori kao o obaveznome činu koji prati vjenčanje. Njegova odredba samo određuje način davanja dosa u slučaju ako se daje. Ova neobvezatnost rečene odredbe u skladu je s praksom u slavonskim gradskim naseljima u kojima miraz srećemo samo iznimno. Res paraphernales u Iločkome statutu ne spominju.

Značenje pojmova dos i res paraphenales u praksi gradskih naselja u srednjovjekovnoj Slavoniji, pa i Gradecu, nije bilo točno određeno. U nekim slučajevima dos je, kao u Tripartitu, bio davanje ženi iz muževljeve imovine nakon njegove

te tako svjedoči i o razdobljima koja su prethodila njegovu nastanku. Ipak, pri njegovu korištenju u istraživanju se mora zadržati oprez. Napose treba uzeti u obzir da Tripartit nije odraz samo postojećega običajnog prava nego i shvaćanja njegova sastavljača Istvána Verbőczyja. Najnovije kritičko izdanje u kojemu je uz latinski original objavljen i njegov prijevod na engleski jezik vidi u: János M. Bak, Péter Banyó, Martyn Rady, prir., The Customary Law of the Renowned Kingdom of Hungary: A Work in Three Parts Rendere by Stephen Werböczy (The "Tripartitum"), The Laws of the Medieval Kingdom of Hungary, 5. sv. (Idyllwild CA; Budimpešta: Charles Schlacks, 2005) (dalje: Tripartit).

${ }_{77}$ Za odredbe vezane uz dos vidi: Tripartit, p.1, t. 93, 174-177; t. 95-97, 176-179; t. 103-105, 184-187; t. 109, 188-189. Opširnije o mirazu prema općemu ugarskom i slavonskom pravu vidi u: Antun Dabinović, Hrvatska državna i pravna povijest (Zagreb: Nakladni zavod Matice hrvatske, 1990), 363-364; Margetić, Hrvatsko srednjovjekovno obiteljsko, 289, 316; Marija Karbić, "Položaj plemkinja u Slavoniji tijekom srednjeg vijeka", Historijski zbornik 59 (2006): 25-27.

${ }^{78}$ Usp. Margetić, Hrvatsko srednjovjekovno obiteljsko, 293; Dabinović, Hrvatska državna, 364.

${ }^{79}$ Glava pod naslovom De marito dante vxori sue res immobiles in signum dotis, que statim deuoluuntur in vxorem iure hereditario glasi: Si quis duxerit vxorem, et in signum dotis res immobiles, videlicet hereditates quascunque in presencii proborum conciuium dederit seu dare promiserit vxori sue, de eisdem de cetero, nullam habebit dandi seu dimittendi, aut legandi facultatem, sed ipsa vxor, eas iure hereditario et perpetuo possidebit (Iločki statut, knj. IV, gl.3, 65). I prema Budimskoj pravnoj knjizi žena je slobodno raspolagala mirazom i drugim što je dobila povodom braka. Usp. Néda Davori Relković, Buda város jogkönyve (Ofner Stadtrecht) (Budimpešta: Stephaneum Nyomda R. T., 1905), 127. Takvo slaganje odredbi moglo se i očekivati jer su i Buda i Ilok bili tavernikalni gradovi te time pripadali istome pravnom sustavu. 
smrti, ali postoje i slučajevi u kojima dos ženi daje sam muž, a i oni u kojima ženini roditelji daju dos mužu.$^{80}$ Res paraphenales u gradečkim vrelima spominju se rjeđe nego dos - i to uglavnom zajedno s njim - te nije moguće utvrditi posebno značenje toga pojma. ${ }^{81}$ Rijetko pojavljivanje miraza u gradskim naseljima srednjovjekovne Slavonije bilo je uvjetovano izjednačenošću muške i ženske djece u nasljednim pravima kao i nasljednim pravom supruge (sigurnim barem u slučaju braka u kojemu je bilo djece). Iako pitanje miraza u gradskim naseljima srednjovjekovne Slavonije zahtijeva daljnja istraživanja, pri čemu bi dodatno svjetlo mogla baciti pomna studija pojedinih slučajeva, u svakome slučaju miraz se u ovim naseljima pojavljuje u različitim okolnostima te se tek ponekad spominje u sklopu isplate potraživanja udovice, koja s ostaviteljem nije imala djece, od strane njegovih nasljednika. S obzirom na raznolikost oblika u kojima se javlja moguće je da je njegova pojava u pojedinim slučajevima odraz praksi u drugim sredinama i pravnim sustavima iz kojih su naseljenici u Gradec dolazili. ${ }^{82}$

Drugo pitanje na koje bi se trebalo osvrnuti u vezi s ishodom spora oko nasljedstva između Katarine i sinova Petra Šafara i koje nam više može pomoći pri razumijevanju nasljednih prava udovice $\mathrm{u}$ braku bez djece jest važnost oporuke na Gradecu. ${ }^{83}$ I Apostolova Maršavelski, govoreći o nasljednom pravu supruge u braku bez djece, naglašava da je oporuka mogla eliminirati primjenu načela paterna paternis te da su supruge i u brakovima bez djece oporučnim raspolaganjem svojega muža redovito postajale nasljednicama njegove imovine u gradečkoj praksi 14. i 15. stoljeća. No, ne bismo li mogli prilikom interpretacije slučaja ostavštine Petra Šafara ovu tvrdnju i obrnuti? Nije li možda u ovome slučaju primijenjeno načelo paterna paternis materna maternis zbog toga što je bilo u skladu s Petrovom željom? (U dokumentu je, naime, navedeno da je on imetak ostavio sinovima.) Ovakva interpretacija čini se još vjerojatnijom ako uzmemo u obzir i druge slučajeve koji govore u prilog mišljenju da je bračni drug i u braku bez djece jedini i prvi nasljednik i bez postojanja oporuke u njegovu korist. ${ }^{84} \mathrm{To}$, na kraju krajeva, govori i odredba gradečkoga magistrata u kojoj stoji: “(...) ut marito intestato decedenti uxor, et uxore intestate decedente maritus adiventur heres." ${ }^{\prime 5}$

\footnotetext{
${ }^{80}$ Usp. Marija Karbić, “Obitelj u gradskim naseljima srednjovjekovne Slavonije (13.-16. stoljeće)” (magistarski rad, Sveučilište u Zagrebu, 2001), 46-49; Ista, "Women and Property", 445-446.

${ }^{81}$ Za moguće značenje res paraphernales na Gradecu vidi: Margetić, Hrvatsko srednjovjekovno obiteljsko, 293-294. Neke primjere javljanja res paraphernales u gradovima srednjovjekovne Slavonije vidi u: Karbić, “Obitelj", 49-50.

${ }^{82}$ Stanovništvo Gradeca činili su došljaci s raznih strana, što je, razumljivo, utjecalo i na pravni sustav i običaje koje ondje susrećemo. Usp. Apostolova Maršavelski, Iz pravne prošlosti, 31-34.

${ }^{83} \mathrm{O}$ mogućnostima oporučnoga raspolaganja u gradskim naseljima srednjovjekovne Slavonije vidi: Apostolova Maršavelski, Iz pravne prošlosti, 149-160.

${ }^{84}$ Usp. Margetić, Hrvatsko obiteljsko nasljedno, 327. Nekoliko primjera iz gradečkih spisa koji svjedoče da je bračni drug i u braku bez djece jedini i prvi nasljednik i bez postojanja oporuke u njegovu korist vidi u: $M C Z$, sv. 6: 34, 141, 310, 405.
}

${ }^{85} M C Z$, sv. 6: 133 . 
No, bez obzira na već rečeno, u pitanju nasljednoga prava preživjeloga supružnika u braku bez djece potreban je oprez. Postoje slučajevi na koje je upozorila Magdalena Apostolova Maršavelski i koji govore o primjeni načela paterna paternis materna maternis u takvim slučajevima. U jedan od njih umiješana je ponovno obitelj Šafar. Naime, Agneza, kći uglednog građanina Klementa Pravdića i udovica Andrije Šafara, vodi 1429. spor oko nasljedstva s Andrijinim bratom Petrom i gubi ga. Sud je zaključio da budući da u braku nije bilo djece, a nije postojala ni oporuka, nasljedstvo pripada Andrijinom bratu Petru. ${ }^{86}$ Problem načela nasljeđivanja na Gradecu svakako traži dalje istraživanje.

Pritom se ne smije s uma smetnuti značenje oporuke, a o kojem svjedoči i slučaj Margarete, supruge Brcka ribara. Margareta je, naime, naslijedila cijeli Brckov imetak per legacionem testamentariam prefati Briccii piscatoris, iako su postojali potomci Brckove kćeri Margarete i suca Benedikta, koji su također na njih imali nasljedno pravo. U Margaretino vlasništvo tako su došle dvije kuće s pripadajućim zemljištem i objektima, kao i vrt i više obradivih zemljišta. ${ }^{87}$

Velika uloga koju su u prijenosu imovine imale pripadnice gradske elite najviše dolazi do izražaja u darovanjima nekretnina bračnome drugu, koje je na Gradecu bilo uobičajena pojava. Iako su zabilježeni i slučajevi u kojima su žene primile darovanja od svojih supruga, ${ }^{88}$ mnogo je češći bio obrnut slučaj, to jest darovanje žene suprugu. Darovanjem su nekretnine prelazile u imovinsku masu obdarenika te je ustanova darovanja za muža bila povoljnija nego institut miraza na koga je muž imao samo pravo uživanja i s kojim je mogao raspolagati samo uz ženinu suglasnost. No, treba napomenuti da je u nekim slučajevima žena mužu darovala uz uvjet da joj darovano bude vraćeno ako muž umre prvi. Ustanova darovanja mužu rezultat je imovinskih odnosa u braku u gradskim naseljima srednjovjekovne Slavonije, odnosno pluraliteta imovinskih masa koji je bio karakterističan za brak u tim naseljima, te povoljnoga imovinskog položaja žene u njima. ${ }^{89}$ Činjenica da su u braku oba supružnika, kako muž tako i žena, zadržavala svoju imovinu, da su s njome samostalno upravljali i poslovali, što je ponekad dovodilo čak i do međusobnoga poslovanja, omogućila je ovakva darovanja, ali i dovodila do njih..$^{90}$

\footnotetext{
${ }^{86} M C Z$, sv. 9: 181-182. Usp. i Apostolova Maršavelski, Iz pravne prošlosti, 142-143.

${ }^{87} M C Z$, sv. 10: 71.

${ }^{88}$ Karbić, "Women and Property", 446.

${ }^{89} \mathrm{O}$ ustanovi darovanja nekretnina bračnome drugu vidi: Apostolova Maršavelski, Iz pravne prošlosti, 62-63.

${ }^{90}$ O imovinskim odnosima u braku vidi: Karbić, "Women and Property", 447-450. Uz to što je svaki supružnik imao svoju imovinu, supružnici su neku imovinu mogli imati i zajedno. Tako je, na primjer, Katarina zajedno sa svojim trećim mužem Matijom Farkašem kupila od općine neke posjede ( $M C Z$, sv. 10: 18). Te je posjede općina oduzela Jakovu, sinu Petra Šafara zbog nekih zlodjela, a radilo se zapravo o posjedima koje je Jakov naslijedio od Katarinine kćeri Margarete i koje su prije podjele imovine između Katarine i Margarete bili u zajedničkome vlasništvu. Ovaj slučaj pokazuje nam i nastojanje pojedinca da vrati posjede koji su u međuvremenu bili otuđeni.
} 
Lijep primjer takvoga darovanja suprugu pruža nam i Franciska Donati, koja je 1397. svom drugom suprugu Ivanu Gracinu poklonila toranj, palaču te kapelu sv. Uršule. ${ }^{91}$ I u slučaju Katarine, supruge Franciskina sina Žigmunda jurata, pa Petra Šafara i naposljetku Matije Farkaša, nalazimo primjer darovanja suprugu. Ona je svome trećem suprugu Matiji Farkašu poklonila polovicu svoje palače, drvenih zgrada, pripadajućih objekata i zemljišta u devetoj insuli, dok je drugu polovicu navedenih nekretnina zadržala za sebe. ${ }^{92}$ Ipak, iako je Matija tim darovanjem stekao vrijedan imutak, treba reći da je on i bez toga bio imućan građanin, vlasnik više različitih posjeda. ${ }^{93}$ Ovdje treba spomenuti i da je Katarina, nakon što je i po treći put ostala udovica, poklonila 1451. neke nekretnine i Jurju Maretiću, suprugu svoje sestre Elizabete. ${ }^{94}$

Primjer darovanja nekretnina bračnome drugu nalazimo i u slučajevima drugih istaknutih građanki o kojima smo govorili. Katarina, tada udovica Mihaela, sina Jurja Barbata, poklanja 1441. godine cijeli svoj dio kuće i vrta iza Novih vrata svome novom mužu Sebastijanu Soldinaru. ${ }^{95}$ Petnaest godina kasnije (1456.) Katarina, tada već Sebastijanova udovica, poklanja svome novom mužu Antunu Rothu sve posjede koje je naslijedila od svoga muža Sebastijana: kuće, dućane, vrtove, vinograde, oranice i sjenike. Zatim Katarina i Antun sklapaju dogovor kojim se žele osigurati u slučaju smrti jednoga od njih: Antun daje u polog stotinu florena, a Katarina dvije stotine pod uvjetom da, ako Antun umre prije Katarine, onda ona dobiva njegov novac, a ako Katarina umre prije, Antun dobiva dvjesto florena uz izričitu napomenu da na taj novac ne mogu polagati pravo njegova braća i rođaci kao ni Katarinina djeca. ${ }^{96}$

Ovdje bi trebalo upozoriti da, iako u načelu darovanjem posjed prelazi u vlasništvo obdarenika te bi on njime trebao slobodno gospodariti, to nije uvijek bio slučaj. Tako, na primjer, Ivanu Gracinu nije dopušteno da dio imovine koji je dobio od svoje žene Franciske daruje kćeri Elizabeti. Sud je odlučio da Elizabeta taj posjed može naslijediti tek nakon Franciskine smrti. ${ }^{97}$ Vjerojatno se ovdje radilo o darovanju pod uvjetom da imovina bude vraćena Franciski ako Ivan umre prije nje. Stoga Ivan i nije imovinom mogao slobodno raspolagati dok je ona bila živa. Kao što smo vidjeli i iz navedenih primjera, darovanja su bila osobito česta kada se radilo o brakovima udovica. Ta nas činjenica vodi prema još jednoj od značajki braka na Gradecu, koja je imala veliki utjecaj i na formiranje gradske elite

\footnotetext{
${ }^{91}$ MCZ, sv. 9: 91.

${ }_{92}$ MCZ, sv. 9: 269-270. Usp. Bedenko, Zagrebački Gradec, 59.

${ }^{93}$ Za Matijine posjede vidi, npr.: MCZ, sv. 9: 128; sv. 10: 9, 26. Usp. i: Škreblin, "Pripadnici plemićke zajednice", 73-74.

${ }^{94}$ MCZ, sv. 10: 129.

${ }^{95}$ MCZ, sv. 10: 7.

${ }^{96}$ MCZ, sv. 10: 167.

${ }_{97}$ Bedenko, Zagrebački Gradec, 44-45.
} 
te stvaranje mreža među njezinim članovima. Naime, česta pojava u slavonskim gradovima bilo je ponovno sklapanje braka udovaca i udovica.

Iako je službeni stav Crkve od 13. stoljeća bio da su drugi i svaki sljedeći brak udovaca i udovica dopušteni, Crkva nije gledala s odobravanjem na ponovnu ženidbu/udaju preživjeloga supružnika. Stajalište civilnih vlasti također je bilo nepovoljno te su one često određivali vremenski period koji je morao proći između smrti supružnika i sklapanja novoga braka, a nekad su i sprječavale ponovnu ženidbu ljudi koji nisu riješili imovinsko-pravne odnose vezane uz prethodni brak. U nekim je slučajevima novi brak mogao dovesti i do gubitka skrbništva nad djecom iz prvoga braka. ${ }^{98}$

Nasuprot ovakvim gledanjima prisutnima u Crkvi ili u nekim drugim sredinama pa i, na primjer, u dalmatinskim gradovima - iz gradskih naselja srednjovjekovne Slavonije nisu nam poznata nikakva ograničenja za sklapanje ponovnoga braka udovaca i udovica niti je novi brak dovodio do gubitka skrbništva nad djecom iz prethodnoga braka. Pojava ponovnoga sklapanja braka jednako je bila prisutna i kod udovaca i kod udovica. Tako često sklapanje ponovnoga braka udovaca i udovica proizlazi iz zahtjeva svakodnevnoga života stanovništva slavonskih gradskih naselja. U obiteljima sitnih i srednjih trgovaca i obrtnika od velike je važnosti rad obaju supružnika te je onome tko ostane sam nakon smrti supružnika život bio znatno otežan. Napose je to bio slučaj s udovicama, kojima je, iako su i same mogle nastaviti poslovanje, dobro dolazila pomoć u daljnjem bavljenju obrtom ili trgovinom. ${ }^{99}$ Struktura obitelji kakva je prevladavala u njima, to jest jednostavna obitelj, također je pogodovala sklapanju ponovnih brakova. ${ }^{100}$ Udovcu ili udovici koji ostanu sami potrebniji je ponovni brak nego onima koji žive u složenim obiteljima, kako materijalno, tako i psihički. ${ }^{101}$ Navedeno je vrijedilo i za one bogatije među njima pa i za pripadnice gradske elite kojima smo se ovom prilikom bavili. Uz to, što su ponovni brakovi udovaca i udovica iz krugova gradske elite, kao što smo već vidjeli, imali i ulogu povezivanja članova elite i njezine konsolidacije.

Jedno od pitanja koje bi u vezi s ulogom pripadnica elite u njezinu formiranju trebalo postaviti jest koliko su one pritom bile aktivan čimbenik, a koliko samo

\footnotetext{
${ }^{98}$ James A. Brundage, “The Merry Widow's Serious Sister: Remarriage in Classical Canon Law”, u: Matrons and Marginal Women in Medieval Society, uredili Robert R. Edwards i Vickie Ziegler (Woodbridge: The Boydel Press, 1995), 33-48; Isti, Law, Sex and Christian Society in Medieval Europe (Chicago: Chicago University Press, 1987), 477-478, 540; Janeković Römer, Rod i grad, 58-59, 67-68.

${ }_{99}$ U kasnosrednjovjekovnom Sopronu obrtnička zajednica vršila je pritisak na udovicu da se ponovno uda te time osnaži kako poziciju obitelji tako i poslovanje. Usp. Katalin G. Szende, "Craftmen's Widows in Late Medieval Sopron", u: Women in Towns. The Social Position of European Urban Women in a Historical Context, uredili Marjata Hietalla i Lars Nilsson (Stockholm: Stads- och kommunhistoriska institutet, Stockholm universitet, 1999), 19.

${ }^{100}$ Karbić, “Obitelj”, 37-38.

${ }^{101} \mathrm{Iz}$ istih je razloga dolazilo i do česte ponovne ženidbe/udaje preživjeloga supružnika i u ugarskim gradovima. O ponovnim brakovima udovaca i udovica bavila se na primjeru Soprona i Požuna K. Szende. Usp. Szende, “The Other Half”, 177, 182.
} 
sredstvo kojim su se drugi služili. Na primjer, je li im bračne partnere birala obitelj u skladu s obiteljskom politikom/interesima ili su ih birale same? Na takva pitanja, nažalost, s obzirom na vrela kojima raspolažemo, ne možemo sa sigurnošću odgovoriti te se njima ovom prilikom nismo ni bavili. U vezi s njima možemo se jedino zadržati na pretpostavki da je utjecaj obitelji bio veći, pa i odlučujući, u slučaju djevojaka, dok su udovice vjerojatno bile samostalnije u odlukama.

Kada govorimo o pripadnicama gradečke elite, mogli bismo obraditi i različite druge teme, govoriti o njihovu poslovanju ili uključenosti u promet nekretninama ili sudjelovanju u sudskim postupcima, no na svim tim područjima one su djelovale na isti način i uživale ista prava kao i druge građanke. Stoga smo se ovom prilikom zadržali na onome po čemu su se od njih razlikovale, odnosno na njihovim obiteljskim vezama, društvenome ugledu koji su uživale i imetku kojim su raspolagale. Iako je istraživanje provedeno na ograničenome uzorku, i iz navedenih primjera vidljivo je da su pripadnice elite igrale važnu ulogu kako u očuvanju pojedinih obitelji, njihova imetka i ugleda (makar kroz žensku liniju), tako i u uključivanju novih članova u vladajuće gradske krugove te time i u obnavljanju i formiranju elite. 


\section{Objavljeni izvori i literatura}

Apostolova Maršavelski, Magdalena. Iz pravne prošlosti Zagreba (13.-16. stoljeće). Zagreb: Školska knjiga, 1998.

Bak, János M.; Banyó, Péter; Rady, Martyn, prir., The Customary Law of the Renowned Kingdom of Hungary: A Work in Three Parts Rendere by Stephen Werböczy (The "Tripartitum"). The Laws of the Medieval Kingdom of Hungary, 5. sv. Idyllwild CA- Budimpešta: Charles Schlacks, 2005.

Barbarić, Josip; Kolanović, Josip, prir. Zapisnici poglavarstva slobodnog i kraljevskog grada Varaždina, sv. 3. Varaždin: Historijski arhiv Varaždin, 1992.

Bedenko, Vladimir. "Društvo i prostor srednjovjekovnoga Gradeca”. U: Zagrebački Gradec 1242. - 1850., uredili Ivan Kampuš, Lujo Margetić i Franjo Šanjek, 37-49. Zagreb: Grad Zagreb, 1994.

Bedenko, Vladimir. Zagrebački Gradec. Kuća i grad u srednjem vijeku. Zagreb: Školska knjiga, 1989.

Brundage, James A. Law, Sex and Christian Society in Medieval Europe. Chicago: Chicago University Press, 1987.

Brundage, James A. “The Merry Widow’s Serious Sister: Remarriage in Classical Canon Law". U: Matrons and Marginal Women in Medieval Society, uredili Robert R. Edwards i Vickie Ziegler, 33-48. Woodbridge: The Boydel Press, 1995.

Carpenter, Charlotte. "The Formation of Urban Élites: Civic Officials in LateMedieval York 1476-1525”. Doktorski rad, University of York, 2000.

Čoralić, Lovorka. “Zemljišni posjed i poslovanje građana Gradeca prema zemljišnim knjigama 14-15. stoljeća”. U: Zagrebački Gradec 1242. - 1850., uredili Ivan Kampuš, Lujo Margetić i Franjo Šanjek, 109-127. Zagreb: Grad Zagreb, 1994.

Dabinović, Antun. Hrvatska državna i pravna povijest. Zagreb: Nakladni zavod Matice hrvatske, 1990.

Davori Relković, Néda. Buda város jogkönyve (Ofner Stadtrecht). Budimpešta: Stephaneum Nyomda R. T., 1905.

Eliassen, Finn-Einar. "The Son-in-Law Principle: Dynasties in Government and Trades in Early Modern Danish and Norwegian Towns". U: Generations in Towns: Succession and Success in Pre-Industrial Urban Societies, uredili Finn-Einar Eliassen i Katalin Szende, 257-281. Newcastle upon Tyne: Cambridge Scholars Publishing, 2009.

Flóra, Ágnes. "From decent stock': Generations in Urban Politics in SixteenthCentury Transilvania”. U: Generations in Towns: Succession and Success in PreIndustrial Urban Societies, uredili Finn-Einar Eliassen i Katalin Szende, 210-231. Newcastle upon Tyne: Cambridge Scholars Publishing, 2009.

Howell, Marta C. "Citizenship and Gender: Women Political Status in Northern Medieval Cities". U: Women and Power in the Middle Ages, uredile Mary Erler i 
Maryanne Kowaleski, 37-60. Athens; London: The University of Georgia Press, 1988.

Jacobsen, Grethe. "Kirstine Buddes, Else Wessels und eine unbekannte Sattlerwitwe - dänische Städtebgerinnen im 15/16. Jahrhundert". U: Fürstinnen und Städterinnen. Frauen im Mittelalter, uredili Gerald Beyreuther, Barbara Pätzold i Erika Uitz, 142-163. Freiburg; Basel; Wien: Herder, 1993.

Janeković Römer, Zdenka. Rod i grad: dubrovačka obitelj od XIII. do XV. stoljeća. Zagreb: HAZU, 1994.

Karbić, Marija. “Nije, naime, njezina duša drugačija nego kod muškarca’ - položaj žene u gradskim naseljima međurječja Save i Drave u razvijenom i kasnom srednjem vijeku". U: Žene u Hrvatskoj. Ženska i kulturna povijest, uredila Andrea Feldman, 57-76. Zagreb: Institut Vlado Gotovac; Ženska infoteka, 2004.

Karbić, Marija. "Obitelj u gradskim naseljima srednjovjekovne Slavonije (13.-16. stoljeće)”. Magistarski rad, Sveučilište u Zagrebu, 2001.

Karbić, Marija. "Položaj plemkinja u Slavoniji tijekom srednjeg vijeka". Historijski zbornik 59 (2006): 15-31.

Karbić, Marija. "The Role of Women in the Economic Life of Medieval Slavonian Towns as Reflected in Urban Legislation and Everyday Life". U: East meets West: A Gendered View of Legal Tradition. Sixth Conference of the International Research Nerwork "Gender Differences in the History of European Legal Cultures", Budapest March 10th - 12th 2011, uredile Grethe Jacobsen i Heide Wunder, 130-140. Kiel: Solivagus Verlag, 2015.

Karbić, Marija. "Women and Property in Medieval Slavonian Towns". U: Towns and Cities of the Croatian Middle Ages: Authority and Property, uredile Irena Benyovsky Latin i Zrinka Pešorda Vardić, 439-454. Zagreb: Hrvatski institut za povijest, 2014.

Kermode, Jenny. "Sentiment and Survival: Family and Friends in Late Medieval English Towns”. Journal of Family History 24 (1999), br. 1: 5-18.

Klaić, Nada. Zagreb u srednjem vijeku. Zagreb: Sveučilišna naklada Liber, 1982.

Margetić, Lujo. "Iločka pravna knjiga (tzv. Iločki statut)". Zbornik Pravnog fakulteta u Zagrebu 44 (1994), br. 1-2: 93-116.

Margetić, Lujo. Hrvatsko srednjovjekovno obiteljsko i nasljedno pravo. Zagreb: Narodne novine, 1996.

Mertanová, Štefánia. Ius tavernicale: stúdie o procese formovania práva taverníckych miest $v$ etapách vývoja taverniíckeho súdu v Uhorsku (15.-17. stor.). Bratislava: Slovenskej Akademie Vied, 1985.

Schmidt, Rudolf. Statut grada Iloka iz godine 1525. Monumenta historico-juridica Slavorum Meridionalium, vol. 12. Zagreb: JAZU, 1938. 
Shahar, Shulamith. The Fourth Estate. A history of women in the Middle Ages. London; New York: Routledge, 1996.

Szende, Katalin G. "Craftmen's Widows in Late Medieval Sopron". U: Women in Towns. The Social Position of European Urban Women in a Historical Context, uredili Marjata Hietalla i Lars Nilsson, 13-21. Stockholm: Stads- och kommunhistoriska institute, Stockholm universitet, 1999.

Szende, Katalin G. "The Other Half of the Town: Women in Private, Professional and Public Life in Two Towns of Late Medieval Western Hungary". U: Women and Power in East Central Europe - Medieval and Modern, uredila Marianne Sághy. East Central Europe 20-23/1 (1993-1996), 171-190.

Škreblin, Bruno."Etničke i političke skupine u srednjovjekovnom gradu. Primjer gradečkih lingui". Povijesni prilozi 35 (2008): 91-148.

Škreblin, Bruno. "Nijemci na Gradecu sredinom i u drugoj polovini 15. stoljeća". Godišnjak njemačke zajednice - DG Jahrbuch 17 (2010): 33-54.

Škreblin, Bruno. "Njemački trgovci na srednjovjekovnom Gradecu”. Godišnjak njemačke zajednice - DG Jahrbuch 20 (2013): 195-206.

Škreblin, Bruno. “Obitelj Šafar - iz života jedne njemačke obitelji”. Godišnjak njemačke zajednice - DG Jahrbuch 16 (2009): 83-100.

Škreblin, Bruno. "Pripadnici plemićke zajednice iz Klokoča na zagrebačkom Gradecu u 15. stoljeću: Primjer uloge sitnog plemstva u formiranju urbanih elita". U: Ascendere historiam. Zbornik u čast Milana Kruheka, uredili Marija Karbić, Hrvoje Kekez, Ana Novak i Zorislav Horvat, 67-80. Zagreb: Hrvatski institut za povijest, 2014.

Škreblin, Bruno. "Uloga obiteljskih veza u formiranju gradske elite zagrebačkog Gradeca”. Zbornik Odsjeka za povijesne znanosti Zavoda za povijesne i društvene znanosti HAZU 34 (2016): 39-87.

Škreblin, Bruno. "Urbana elita zagrebačkog Gradeca u 15. i početkom 16. st. Primjeri nekolicine uglednih gradečkih građana”. U: Mestne elite $v$ srednjem in zgodnjem novem veku med Alpami, Jadranom in Panonskom nižinom / Urban elites in the Middle Ages and the Early Modern Times between the Alps, the Adriatic and the Pannonian Plain, uredili Janez Mlinar i Bojan Balkovec, Zbirka Zgodovinskega časopisa 42, 308-322. Ljubljana: Zveza zgodovinskih društev Slovenije, 2011.

Tkalčić, Ivan Krstitelj. Povjestni spomenici slob. kralj. grada Zagreba. Monumenta historica liberae regiae civitatis Zagrabiae, sv. 1-11. Zagreb: Grad Zagreb, 18891905.

Vitek, Darko. "Struktura i izvorište teksta Iločkog statuta". Scrinia Slavonica 1 (2001): 404-420. 


\title{
Concealed power: The role of the female members of the city elite in the political, social and economic life of Zagreb Gradec
}

\author{
Marija Karbić \\ Croatian Institute of History \\ Department of History of Slavonia, Syrmia and Baranya \\ Starčevićeva 8 \\ 35000 Slavonski Brod \\ Croatia \\ E-mail: mkarbic@isp.hr \\ Bruno Škreblin \\ Croatian Institute of History \\ Opatička 10 \\ 10000 Zagreb \\ Croatia \\ E-mail: bruno@isp.hr
}

\section{Summary}

Although women in medieval towns could not participate neither in the city government nor in the election of the city officers, they had influence in the shaping of the urban elite, as is demonstrated in this article on the example of Zagreb Gradec. Women in the medieval city of Zagreb were able to obtain the full right citizenship, which allowed them certain privileges. Besides that, they were treated equally to male heirs according to the inheritance law. They were also treated equally in many other aspects of the urban life such as trade or in the city court. Some women were among the richest inhabitants of the city community, as were Francisca Donati, Margareta Rybarica, Katarina, the widow of Sigismund Mauri, or Katarina Soldinar. Furthemore, the usual way of integration of the new members of the urban elite was marriage into a family which already belonged to the urban elite, whether by marrying a daughter of the prominent citizen who was a judge or a juror, or by marrying a widow of the former member of the elite. Good marriage often proved to be more useful for political climb than regular kinship ties by blood. In that way, prominent women played a great role in the integration or consolidation of the urban elite.

Key words: history of women, urban elite, medieval Slavonia, inheritance law 